\title{
Soil Solarization in Established Avocado Trees for Control of Dematophora necatrix
}

C. J. López-Herrera and R. M. Pérez-Jiménez, Estación Experimental La Mayora, C.S.I.C., 29750, AlgarroboCosta, Málaga, Spain; T. Zea-Bonilla, Centro de Investigación y Formación Agraria, 29140, Churriana, Málaga, Spain; M. J. Basallote-Ureba, Centro de Investigación y Formación Agraria, Apdo.240, 14080, Córdoba, Spain; J. M. Melero-Vara, Instituto de Agricultura Sostenible, C.S.I.C., Apdo. 4084, 14080, Córdoba, Spain

\begin{abstract}
López-Herrera, C. J., Pérez-Jiménez, R. M., Zea-Bonilla, T., Basallote-Ureba, M. J., and Melero-Vara, J. M. 1998. Soil solarization in established avocado trees for control of Dematophora necatrix. Plant Dis. 82:1088-1092.

Four field experiments on the control of Dematophora necatrix in avocado orchards affected by white root rot were conducted in the Mediterranean coastal area of southern Spain during 1991 to 1994. In the unshaded locations of solarized plots, the maximal temperatures were 35 to $42^{\circ} \mathrm{C}$, depending upon the year and soil depth $(15$ to $60 \mathrm{~cm})$. Temperature increases attributable to soil solarization ranged between 4 and $8^{\circ} \mathrm{C}$ in unshaded areas, whereas for shaded areas they were approximately $4^{\circ} \mathrm{C}$. Inoculum recovery was decreased in root samples buried at 15 to 30 $\mathrm{cm}$ in unshaded locations of both solarized and unsolarized plots after 3 to 5 weeks, whereas 4 to 8 weeks of solarization were required for the elimination of the pathogen buried at depths of 45 to $60 \mathrm{~cm}$. In contrast, inoculum recovery ranged from 30 to $60 \%$ for samples in shaded locations of unsolarized plots. D. necatrix was not recovered from roots of infected trees in solarized plots sampled 9 months after solarization, whereas recovery from roots in unsolarized plots was similar to levels before solarization. Soil solarization in established orchards was successful in reducing viability of inoculum buried in soil and eliminated inoculum in infected roots of live trees.
\end{abstract}

Additional keywords: Persea americana, soilborne pathogen, thermal inactivation

Rosellinia necatrix Prill. (anamorph: Dematophora necatrix Hartig), the causal agent of white root rot in avocado and many other crops, has a very wide host range (i.e., 170 plant species or varieties in 63 genera and 30 families of dicotyledonous angiosperms) (9). This fungal pathogen is destructive to many fruit tree crops $(2,8,20)$, including tropical and subtropical species such as avocado (Persea americana Mill.) and mango (Mangifera indica L.), which are particularly susceptible $(9,18,20,24)$.

Disease development in infected trees is usually rapid, killing trees within a few weeks of the first foliar symptoms. Significant losses of avocado trees in 15- to 20year-old orchards in the coastal area of southern Spain have been observed since the first report of the disease in 1986 (11). The pathogen is capable of surviving many years on residue of crops susceptible to $D$. necatrix, such as olive (Olea europaea L.), grapevine (Vitis vinifera L.), and almond

\section{Corresponding author: C. J. López-Herrera E-mail: clherrera@eelm.csic.es}

Accepted for publication 11 June 1998.

Publication no. D-1998-0805-01R

(C) 1998 The American Phytopathological Society
(Prunus amygdalis Batsch.), which were common in the region prior to the introduction of avocado. The high susceptibility of Topa-Topa (14), the rootstock most frequently used in avocado orchards in the area, may have favored the disease increase.

Systemic fungicides, such as the benzimidazoles, phosphorous acid, and PCNB, were effective against the pathogen in tests in vitro and when used as soil drenches on apple $(3,5,16,17,22)$ and avocado plants $(12,13)$. Soil fumigants have also been effective in eradicating the pathogen from fallow soil $(10,21)$.

Soil solarization has been successfully used to control soilborne fungal pathogens such as $R$. necatrix in apple and Verticillium dahliae in established pistachio, avocado, almond, and olive orchards $(1,4,6,7,15,19,23)$.

Thermal sensitivity of different inoculum types of $D$. necatrix has been studied (9), and the use of soil solarization to eradicate this pathogen in infested bare soil has been effective when avocado seedlings were planted in solarized soil (19). However, reduction of the pathogen in established avocado orchards has not been studied. Therefore, the aim of this work was to determine the effect of soil solarization on the viability of $D$. necatrix in established avocado orchards on the southern coast of Spain.

\section{MATERIALS AND METHODS}

Four field experiments (I to IV) were conducted in four avocado orchards (A to D) affected by white root rot. The experiments in orchards A and B were established in 1991 and those in orchards $\mathrm{C}$ and D in 1993 and 1994, respectively.

Experiment I. Orchard A consisted of 10-year-old trees (at $4 \times 4 \mathrm{~m}$ spacing) with a canopy diameter of approximately $3 \mathrm{~m}$. They were cv. Fuerte grafted to Topa-Topa seedling rootstock established in a sandy loam soil $(\mathrm{pH}=7.3$, organic matter $0.9 \%)$. The two treatments, i.e., solarized and unsolarized, had four completely randomized plots, each of $12 \times 7 \mathrm{~m}$. Soil was rototilled $(15 \mathrm{~cm})$ and irrigated to field capacity in the upper $60-\mathrm{cm}$ layer. One nylon net containing five pieces of freshly cut avocado roots $(5 \mathrm{~cm}$ long, 0.5 to $1 \mathrm{~cm}$ thick) naturally infected by $D$. necatrix was buried at 30-cm depth in the soil at each of two locations (shaded and unshaded) in each of the plots at least $1.5 \mathrm{~m}$ from the tarp edge. Simultaneously with root sample burial, thermistors were placed in one plot per treatment at $30-\mathrm{cm}$ depth. For shaded locations, root samples and thermistors were buried close to tree trunks and to the north, whereas unshaded locations were equidistant from two contiguous rows of trees. Thermistors were connected to a data logger to record hourly temperatures calculated as the average of temperatures every $5 \mathrm{~min}$. After placement of samples and thermistors, the area between tree rows was tarped from the trunk base with $3.5-\mathrm{m}$ wide, 75- $\mu$ m-thick transparent polyethylene. Soil solarization was conducted for 5 weeks starting 25 July 1991, and maximum daily air temperature was obtained from the nearest $(1 \mathrm{~km})$ meteorological station. At the end of solarization, root samples were removed from the soil, surface-disinfested by dipping in $1 \%$ aqueous $\mathrm{NaClO}$ solution for $3 \mathrm{~min}$, and plated onto potato dextrose agar (PDA) acidified with $10 \mathrm{ml}$ of a $25 \%$ (vol/vol) aqueous lactic acid per liter. Viability of the mycelium of $D$. necatrix in these samples was assessed after 3 days of incubation at $24^{\circ} \mathrm{C}$ in the dark, and percent root segments yielding $D$. necatrix was determined.

Experiment II. Orchard B consisted of 20-year-old trees $(8 \times 4 \mathrm{~m}$ spacing $)$ in a sandy soil $(\mathrm{pH}=7.6$, organic matter $0.7 \%)$ with a canopy diameter of approximately 6 
$\mathrm{m}$ of cv. Hass grafted to Topa-Topa seedling rootstock, had three completely randomized replicated plots, each of $10 \times 5 \mathrm{~m}$. After angular transformation of the percent recovery of $D$. necatrix on PDA, analysis of variance was conducted to determine significant differences among treatments. Similarly, soil preparation and soil temperature recording were performed as in experiment I, except that root samples and thermistors were placed at $20-\mathrm{cm}$ depth. Solarization was conducted from 25 July to 19 August 1991.

Experiment III. Orchard C consisted of 18-year-old trees of cv. Hass $(8 \times 4 \mathrm{~m}$ spacing) with a canopy diameter of approximately $6 \mathrm{~m}$, grafted to Topa-Topa seedling rootstock established in a sandy loam soil $(\mathrm{pH}=7.8$, organic matter $1.1 \%)$. Three plots, each $8 \times 8 \mathrm{~m}$, including one tree affected by white rot and one contiguous asymptomatic tree, were established as previously described. Procedures were as in experiments I and II, but a double set of infected root samples (10 root segments, 5 $\mathrm{cm}$ long, $0.5 \mathrm{~cm}$ thick, per set) was buried for each treatment and location at depths of 15,30 , and $45 \mathrm{~cm}$ to allow sampling at 4 and 8 weeks after tarping. Assessments of the viability of $D$. necatrix on root samples were evaluated as in 1991. Analysis of variance was performed with angulartransformed data on inoculum recovery, using a split-split-plot design, with the soil treatment being the main plots.

Prior to tarping, trees were laterally pruned in the preceding spring to achieve a higher proportion of solar-radiated soil surface. After having been tarped with 75$\mu \mathrm{m}$-thick polyethylene, soil was irrigated every 5 days with microsprinklers located underneath the plastic. Soil solarization lasted for 8 weeks starting in mid-July 1993.

Trees in solarized and nonsolarized plots in orchard $\mathrm{C}$ were sampled for root infection upon the initiation and the end of the solarization period, and yearly until February 1997. Ten segments from 1- to 3-cmthick roots sampled at $15-$ to $30-\mathrm{cm}$ soil depth of infected trees were plated, after surface disinfestation, onto acidified PDA and incubated at $24^{\circ} \mathrm{C}$ for 2 to 3 days or incubated for 7 days at 22 to $24^{\circ} \mathrm{C}$ in moist chambers. Thereafter, mycelial growth of D. necatrix was evaluated under a microscope.

Experiment IV. Trees in orchard D, soil characteristics, experimental design, and procedures were as in experiment III, but trees were not pruned. Similarly, there was one plot per treatment (solarized and unsolarized), each of $500 \mathrm{~m}^{2}$ containing seven infected trees. Soil temperature was continuously recorded at 15-, 30-, 45-, and 60-cm depth, but there was no record at 15 $\mathrm{cm}$ in solarized unshaded plots. Maximum daily air temperature was obtained from the farm meteorological station. In each plot, three subplots were used for each
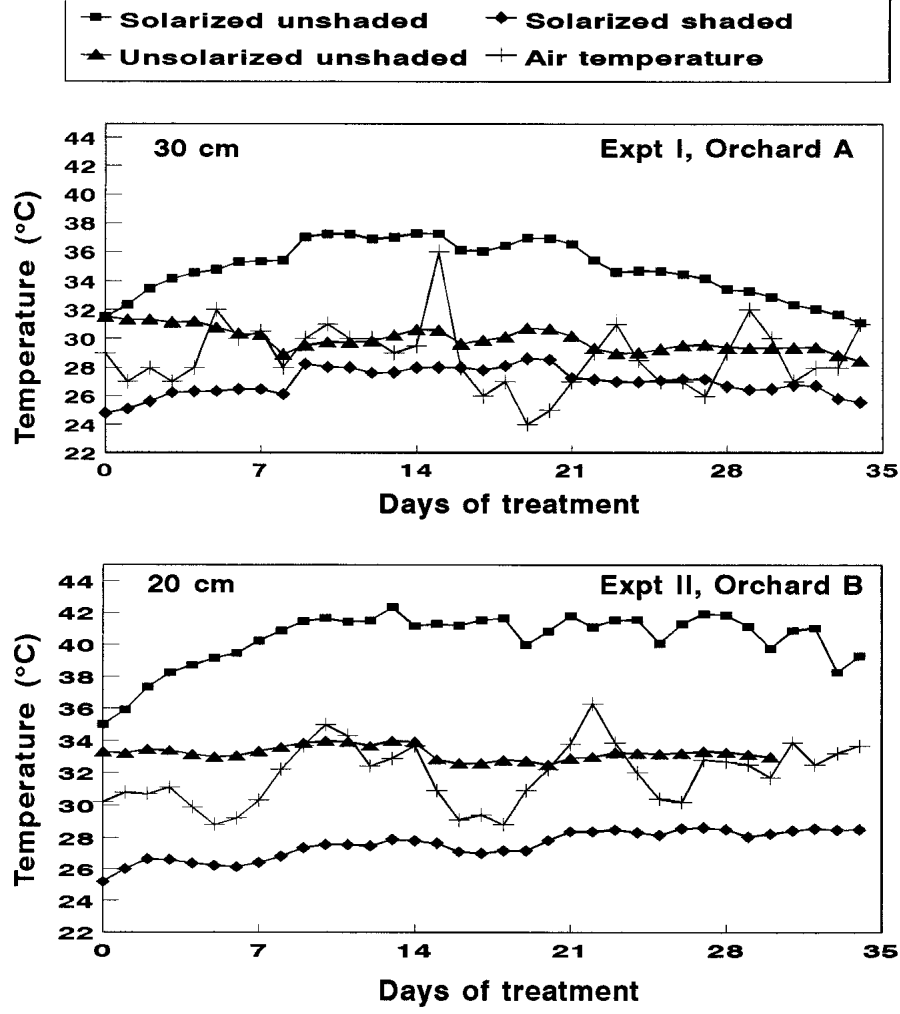

Fig. 1. Maximum air temperatures, and soil temperatures at $30 \mathrm{~cm}$ (orchard A, experiment I) and at $20 \mathrm{~cm}$ (orchard B, experiment II) soil depth in different treatments and locations (unshaded, shaded) during the solarization period 25 July to 29 August 1991.
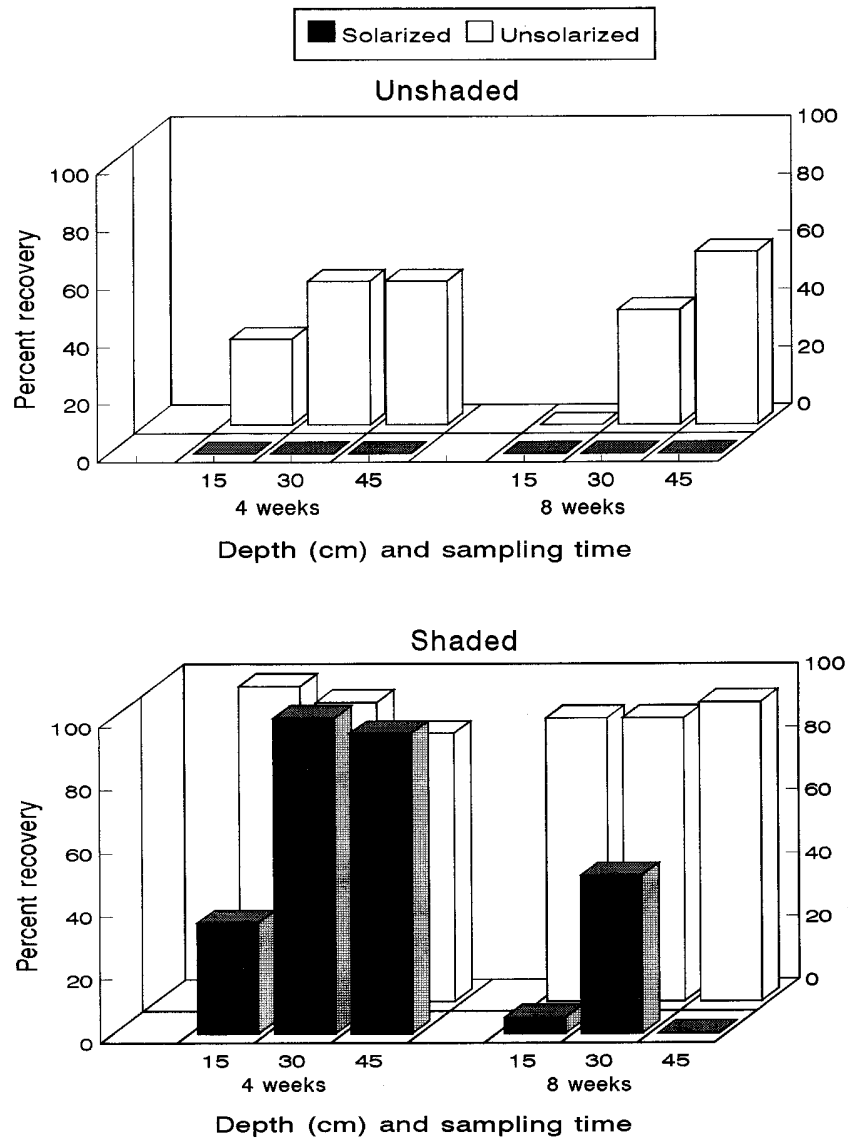

Fig. 2. Percent recovery of Dematophora necatrix after 4 and 8 weeks of solarization in unshaded and shaded locations at different soil depths (orchard C, experiment III, 14 July to 19 September 1993). 
location and depth, and two sets of infected root samples similar to those of experiment III were buried for sampling at 3 and 8 weeks after tarping. Solarization started in mid-July 1994 after irrigating to field capacity. In contrast with the previous experiment, there was no additional irriga- tion during the solarization period, which lasted for 8 weeks. After angular transformation of percent recovery of $D$. necatrix from buried root samples, analysis of variance was performed using a split-split-plot design. Assessments of root infection in trees were conducted as in experiment III,

\begin{tabular}{ll|} 
- Solarized unshaded & - Unsolarized unshaded \\
- Solarized shaded & - Unsolarized shaded \\
+ Air temperature & \\
\hline
\end{tabular}
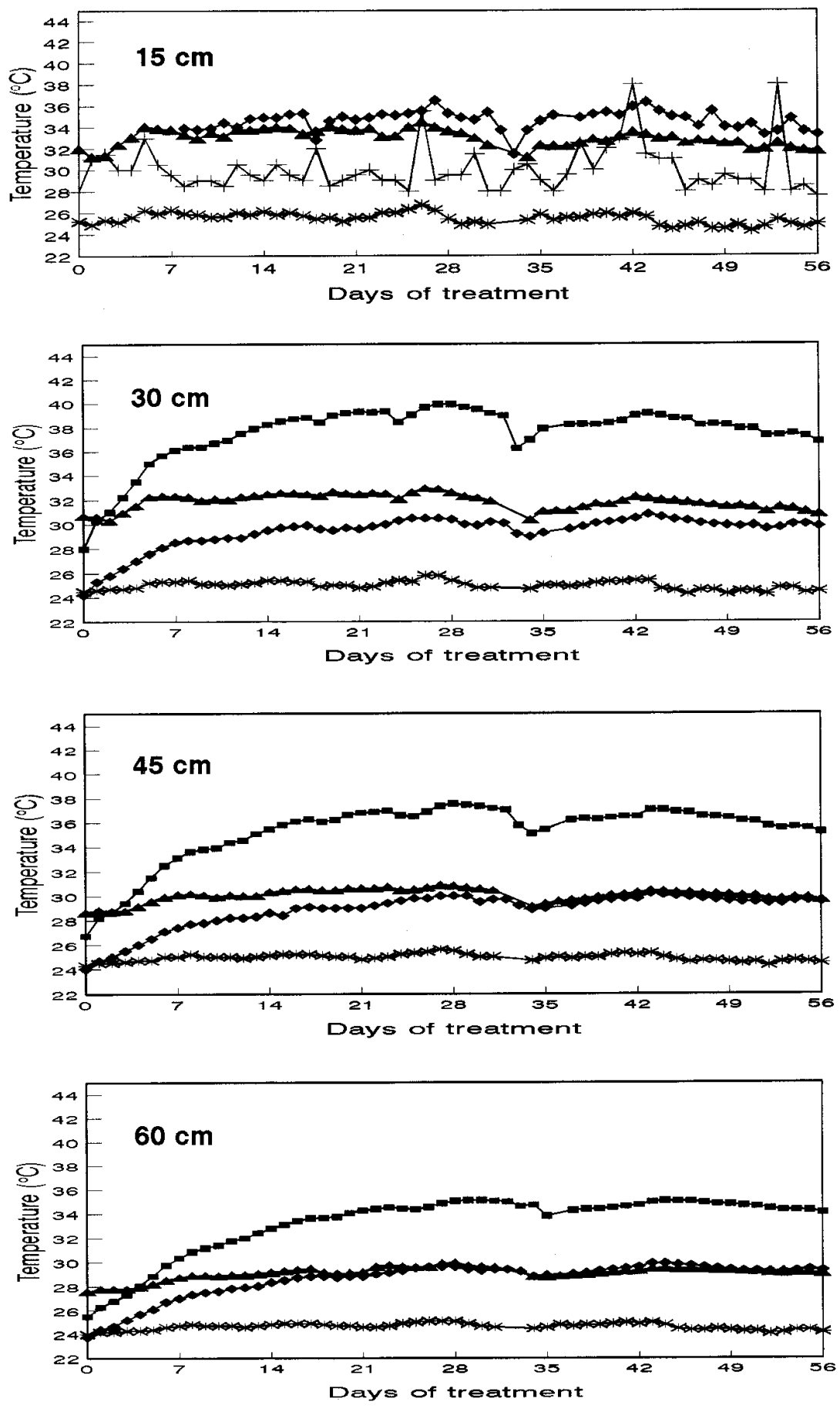

Fig. 3. Maximum air temperature, and soil temperature in different locations (unshaded, shaded) and depths $(15$ to $60 \mathrm{~cm}$ ) during the solarization period 13 July to 14 September 1994 (orchard D, experiment IV). but samplings were performed only until 9 months after solarization.

\section{RESULTS}

Experiments I and II. The maximum temperature in unshaded areas of solarized plots reached $37.3^{\circ} \mathrm{C}$ at $30 \mathrm{~cm}$ (orchard A, Fig. 1A) and $42.3^{\circ} \mathrm{C}$ at $20 \mathrm{~cm}$ (orchard B, Fig. 1B) during the solarization period. The increases when compared with unsolarized plots were 5.8 and $8.3^{\circ} \mathrm{C}$, respectively. Maximum temperatures in shaded areas of solarized plots were $28.6^{\circ} \mathrm{C}$ for the two depths considered. Maximum daily air temperature ranged from 24 to $36^{\circ} \mathrm{C}$ for the locations of orchards A and B (Fig. 1).

After 5 weeks, viability of $D$. necatrix in infected root segments buried at 30- and 20-cm depth (orchards A and B, respectively) was nil in unshaded locations of both solarized and unsolarized plots. With regard to shaded locations, a large reduction in the recovery of $D$. necatrix was noticed in orchard A when unsolarized and solarized plots were compared (90 and $18 \%$ recovery, respectively). Likewise, the recovery of the pathogen in orchard B was $68 \%$ from root segments buried in unsolarized plots, which contrasts $(P=0.0001)$ with the complete elimination of inoculum observed in solarized plots.

Experiment III. Viability of D. necatrix from infected root segments was zero at all soil depths 4 weeks after solarization in unshaded areas and at $15 \mathrm{~cm}$ in unshaded areas of the unsolarized plots after 8 weeks. The high variability in inoculum viability showed significant differences $(P=$ 0.0004 and $P=0.0121$ for 4 and 8 weeks of solarization, respectively) only between shaded and unshaded areas regardless of the treatment and depth of sampling (Fig. 2).

The pathogen was recovered from diseased root samples taken from the trees before initiation of the experiment, with an average of 85 and $70 \%$ for solarized and unsolarized plots, respectively. After removal of the tarp in September 1993, viability of $D$. necatrix in roots sampled from trees in solarized plots was zero, while viability was unaffected in the unsolarized plots. Examinations of roots 3 years after tarping resulted in remission of white root rot symptoms and lack of recovery of $D$. necatrix, whereas symptomatic trees in unsolarized plots died 2 months after tarp removal.

Experiment IV. Average maximum temperatures during the solarization period in the unshaded solarized areas ranged from $37.4^{\circ} \mathrm{C}$ (at $30-\mathrm{cm}$ depth) to $33.2^{\circ} \mathrm{C}$ (at $60-\mathrm{cm}$ depth); whereas in shaded solarized areas, temperatures were 29.4 and $28.6^{\circ} \mathrm{C}$, respectively (Fig. 3). Depending on soil depth, temperature increases attributable to soil solarization were 5.7 to $4.0^{\circ} \mathrm{C}$ in unshaded areas and 4.5 to $4.0^{\circ} \mathrm{C}$ in shaded areas. Maximum daily air temperatures ranged from 28 to $38^{\circ} \mathrm{C}$ (Fig. 3). 
After 3 weeks of solarization, a significant $(P=0.030)$ reduction of mycelium viability from root segments infected by $D$. necatrix was observed regardless of soil depth. Significant differences $(P<0.001)$ between shaded and unshaded locations were also found. The interaction $(P<$ $0.005)$ between treatment and location indicated a higher reduction of mycelium viability due to solarization in the shaded than in the unshaded areas of the solarized plots. The pathogen was killed from all root samples solarized for 8 weeks and from most depths of the unshaded areas of unsolarized plots (Fig. 4).

Recovery of $D$. necatrix from infected roots sampled from diseased trees in orchard D prior to solarization was $90 \%$ in unsolarized plots and $40 \%$ in solarized plots. After 9 months, in the unsolarized plots, the level of fungal viability remained similar, whereas D. necatrix was completely killed in the solarized plots.

\section{DISCUSSION}

In established orchards of avocado in southern Spain, increases of 4 to $8.3^{\circ} \mathrm{C}$ were obtained in solarization plots, depending on soil depth and year, and as expected, temperatures decreased as soil depth increased. Maximum temperature in unshaded locations of unsolarized plots was higher than in shaded locations of solarized plots except at the $15-\mathrm{cm}$ depth (Figs. 1 and 3). This is the result of the high degree of shading provided by unpruned large avocado trees. Based on a previous report (19), the temperature reached in solarized plots was high enough to kill the pathogen from avocado roots.

Variation in the effectiveness of soil solarization was evident from 1991 to 1994. Solarization for 4 weeks of 1993 in shaded locations partially reduced the viability of D. necatrix buried at $15 \mathrm{~cm}$ (Fig. 2), whereas viability was zero in samples buried at $20-\mathrm{cm}$ depth in similar locations
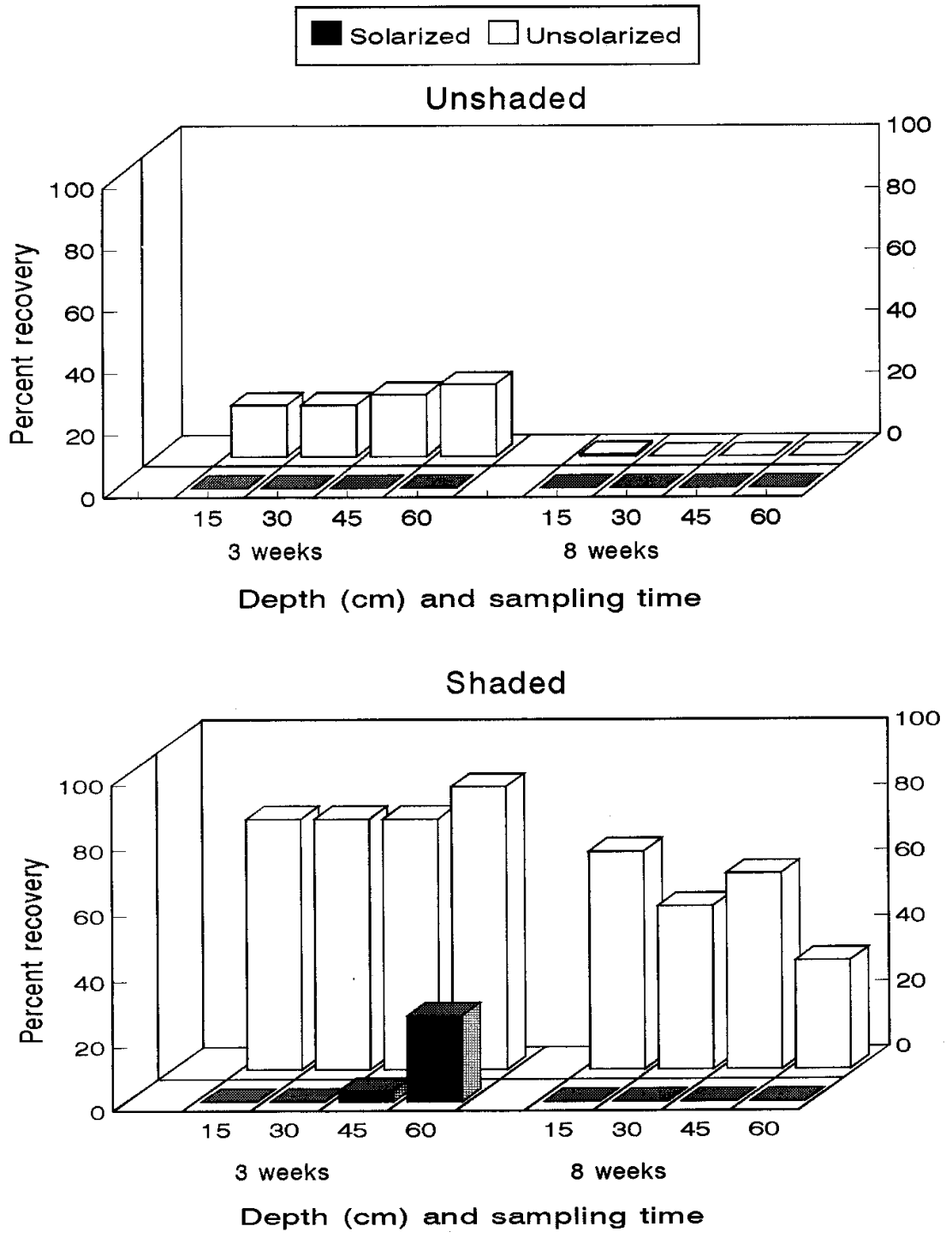

Fig. 4. Percent recovery of Dematophora necatrix after 3 and 8 weeks of solarization in unshaded and shaded locations at different soil depths (orchard D, experiment IV, 13 July to 14 September 1994).

when solarization lasted for 5 weeks (orchard B, 1991), and even at 30-cm depth in the shaded areas of plots solarized for only 3 weeks in 1994 (Fig. 4). Solarization for 8 weeks in 1993 significantly reduced inoculum to a depth of $45 \mathrm{~cm}$ in shaded locations (Fig. 2), whereas 8 weeks of solarization in 1994 eliminated inoculum up to $60-\mathrm{cm}$ depth in the shaded locations (Fig. 4). In contrast, only a partial reduction of inoculum viability after 8 weeks of solarization was observed in the shaded locations of an apple orchard in Israel (19). The unusually mild temperatures during the summer of 1993 (average maximum daily temperatures of $28.4^{\circ} \mathrm{C}$ ) in contrast to $1994\left(29.9^{\circ} \mathrm{C}\right)$ could account for the differences in effectiveness of solarization between these 2 years, emphasizing the need for solarization to be conducted during optimal periods. Irrigation underneath the polyethylene film during solarization in 1993 was used to favor normal tree development during solarization, so that high soil temperature would not impair tree growth and yield. Irrigation should therefore not be recommended unless extremely high temperatures are anticipated and solarization is expected to continue over 2 months.

D. necatrix can be found throughout the soil wherever 1 - to 3 -cm-thick roots are present. In order to control avocado white root rot, solarization must be effective at the deeper soil layers. Evaluations of the pathogen viability from roots in 1993 and 1994 showed it to have been completely killed at a depth of 10 to $15 \mathrm{~cm}$ after 8 weeks of solarization. It is recommended that large areas around affected trees be solarized in order to prevent the infection of roots of surrounding trees. Once symptoms develop, little chance for tree recovery can be expected.

In this work, the effectiveness of solarization to control white root rot in established avocado orchards has been demonstrated and eradication of $D$. necatrix by this method can be achieved down to 60$\mathrm{cm}$ depth. Sequential sampling of infected roots from solarized plots indicates that soil remains pathogen-free for at least 3 years after solarization. This suggests a very slow spread of the pathogen from deep soil layers where solarization is ineffective, to the upper layers where the pathogen had been eradicated. Thus, and in concordance with the previous results obtained in apple orchards (4), solarization would seem to have a long-term effect on this pathosystem.

\section{ACKNOWLEDGMENTS}

This research was supported by INIA Research Project SC93-085 from the MAPA. The authors thank J. M. Casas, J. M. Cobos, and J. Moreno for their technical assistance.

\section{LITERATURE CITED}

1. Ashworth, L. J., Jr., and Gaona, S. A. 1982. Evaluation of clear polyethylene mulch for 
controlling Verticillium wilt in established pistachio nut groves. Phytopathology 72:243-246.

2. Behdad, E. 1975. Morphology, distribution, importance, and hosts of Rosellinia necatrix (Hart.) Berl., the cause of white root rot in Iran. (Abstr.) Iran. J. Plant Pathol. 11:13.

3. Behdad, E. 1976. The influence of several new systemic fungicides on Rosellinia necatrix (Hartig) Berlese. (Abstr.) Iran. J. Plant Pathol. 12:40,

4. Freeman, S., Sztejnberg, A., Shabi, E., and Katan, J. 1990. Long-term effect of soil solarization for the control of Rosellinia necatrix in apple. Crop Prot. 9:312-316.

5. Gupta, V. K. 1978. Possible use of carbendazim in the control of Dematophora root rot of apple. Ind. Phytopathol. 30:527-531.

6. Katan, J. 1981. Solar heating (solarization) of soil for control of soilborne pests. Annu. Rev. Phytopathol. 19:211-236.

7. Katan, J. 1987. Soil solarization. Pages 77105 in: Innovative Approaches to Plant Disease Control. I. Chet, ed. Wiley Interscience Publication, New York

8. Khan, A. H. 1955. Dematophora root rot. Calif. Dep. Agric. Bull. 44:167-170.

9. Khan, A. H. 1959. Biology and pathogenicity of Rosellinia necatrix (Hart.) Berl. Biologia 5:199-425.

10. Kubomura, Y., Ieki, H., and Itoi, S. 1970. Soil disinfestation with chloropicrin against white root rot fungus Rosellinia necatrix (Hart.) Berl. in different soils. Bull. Sericul. Exp. Stn. 24:301-302.

11. López-Herrera, C. J., and Melero-Vara, J. M. 1991. Diseases of avocado caused by soil fungi in the Mediterranean coast of Spain. Pages 119-121 in: Proc. World Avocado Congr. II

12. López-Herrera, C. J., and Pérez-Jiménez, R. M. 1993. Chemical control of Dematophora necatrix with phosphorous acid. Page 49 in: Abstr. Int. Congr. Plant Pathol., 6th.

13. López-Herrera, C. J., Pérez-Jiménez, R. M., and Zea-Bonilla, T. 1996. Control químico de Dematophora necatrix con fungicidas sistémicos. Page 196 in: Prog. Res. Congr. Nacional Soc. Española de Fitopatol., VIII.

14. Raabe, R. D., and Zentmyer, G. A. 1955. Susceptibility of avocado to Dematophora root rot. Calif. Avoc. Soc. Yrbk. 39:172-174.

15. Shabi, E., Pinkas, Y., and Katan, J. 1987. Soil solarization for the control of Verticillium wilt in live orchard trees. (Abstr.) Can. J. Plant Pathol. 9:85-86.

16. Sharma, S. K., and Gupta, V. K. 1985. Movement and persistence of fungicides in apple soils. Ind. Phytopathol. 38:648-652.

17. Shukla, U. S., Nayar, S. K., and Suryanarayana, D. 1973. Laboratory evaluation of fungicides for the control of white root rot disease of temperate fruits caused by Dematophora necatrix. Ind. Phytopathol. 25:417-421.

18. Sivanesan, A., and Holliday, P. 1972. Rosellinia necatrix. Descriptions of Pathogenic Fungi and Bacteria, No. 352. Commonw. Mycol. Inst./Assoc. Appl. Biol., Kew, Surrey, England.

19. Sztejnberg, A., Freeman, S., Chet, I., and Katan, J. 1987. Control of Rosellinia necatrix in soil and in apple orchard by solarization and Trichoderma harzianum. Plant Dis. 71:365-369.

20. Sztejnberg, A., and Madar, Z. 1980. Host range of Dematophora necatrix, the cause of white root rot disease in fruit trees. Plant Dis. 64:662-664.

21. Sztejnberg, A., Omary, N., and Pinkas, Y. 1983. Control of Rosellinia necatrix by deep placement and hot treatment with methyl bromide. EPPO Bull. 13:483-485

22. Teixeira de Sousa, A. J. 1985. Lutte contre Rosellinia necatrix (Hartig) Berlese, agent du pourridité laineux: Sensibilité de quelques espéces végétales et lutte chimique. Eur. J. For. Pathol. 15:323-332.

23. Tjamos, E. C., Paplomatas, E. J., and Biris, D. A. 1987. Recovery of Verticillium dahliae from olive trees after individual application of soil solarization. (Abstr.) Can. J. Plant Pathol. 9:86-87.

24. Zentmyer, G. A. 1984. Avocado diseases. Trop. Pest Manage. 30:388-400. 